\title{
Influence of differentiation strategy on performance of hotels: the moderating role of environmental munificence
}

\author{
Abdullahi Hassan Gorondutse \\ Haim Hilman \\ School of Business Management, \\ University Utara Malaysia.
}

\begin{abstract}
Keywords
Differentiation strategy, Environmental Munificence, Performance and Hotels
\end{abstract}

\begin{abstract}
This study investigates whether environmental munificence directly and indirectly predicts the relationship between differentiation strategy and performance. A total of 83 managers from hotels in Kano state were participated. A questionnaire was administered to collect information on socio-demographics and on differentiation strategy, environmental munificence, and performance. Results revealed that differentiation strategy, environmental munificence was positively associated with performance. Environmental munificence fully moderates the relationships of differentiation strategy and performance. This article, apart from its contribution to the business strategy research, has meaningful implications for managers and policy-makers, the future research directions are discussed.
\end{abstract}

Corresponding author: Haim Hilman

Email address for corresponding author: hilman@uum.edu.my

First submission received: 18th February 2017

Revised submission received: 23rd March 2017

Accepted: 3rd April 2017

\section{Introduction}

In today global competitiveness, business can perform better than rivals if they consider one of this strategy (cost leadership and differentiation strategy) combining the two strategies may likely be a difficult and confuse businesses in deciding whether to offer low-cost strategy or high- cost differentiation of services (Porter, 1985; Pehrsson, 2016; Teece, 2010 \& Yulliansyah, et al., 2016). Many researches were concentrated on manufacturing industry (Tang, 2008; Teece et al., 1997; Yulliansyah, et al., 2016), whereas recently there is some few researches uses business level strategy in services sector, but mostly in developing economies (London \& Heart, 2004; Pehrsson , 2016; Yulliansyah, et al., 2016).

Despite wide spread of information technology in emerging markets, the removal or loosening of restriction on economic has resulted the service sector in developing nation embark on high competition, and a source of attracting foreign investors and become the major source of employment in most nation. For instance, in Nigeria Hotels industry is continued to act a major role in enhancing youth employment benefits (Ngandu, 2014). Tourist Report (2012) indicated that international tourist that arrives in Nigeria has shown an greater than before from 1, 031, 000 in 2005 to 1, 186, 800 in 2009, which shows about 15.1\% increase (Tourist Report, 2012). It continue the amount of business tourists, in turn, grow by $17.2 \%$ over this stage, from 618600 to 725200 (Tourist Report, 2012). From 2008 through 2012, the country witness the average annual GDP increase of 7\%, getting US\$262.6 billion in 2012, but base on SMEDAN, 2013 report annual GDP growth drastically decrease to 1.7 percent in 2014 (National Bureau of Statistics, 2014). 
A business that operates in a active local environment that experience high completion pressure, usually might have advantage employing differentiation strategy, this indicate that differentiation strategy emphasis struggle features which other rivals does have and this brings local competitive advantage as a result may strengthen the global competitiveness (Figueiredo, 2011; Pehrsson , 2016). However, previous literature on emerging nations mainly focused on manufacturing sector and specifically on multinational corporations in seeking competition advantage (Teece, 2010; Pehrsson, 2016; Yulliansyah, et al., 2016). Thus few is known about the strategic alternative made by service markets, or how the regulatory environment influence the operation of organization (Cavusgi et al., 2013 \& Yulliansyah, et al., 2016). This paper addresses this gap by studying the relationship between differentiation strategy and performance hotels with moderating role of environmental munificence in the context of Nigeria.

\section{Literature Review and Hypotheses}

Differentiation strategies are all-encompassing in market economies and are a prevailing means of getting competitive advantages (Hingley, Sodano, \& Lindgreen, 2008; Pehrsson, 2016). Literature in strategic management gives several classification of business strategy that explains how firms compete in their relevant market environments (Cavusgi et al., 2013; Hingley, Sodano, \& Lindgreen, 2008; Pehrsson, 2016 \& Yulliansyah, et al., 2016).

Porter's differentiation strategy gives businesses chance to declare a best price besides retaining better market share or becoming as market leader (Allen \& Helms, 2006). The differentiation strategy as part of business level strategy is resourcefully executed when the businesses gives exclusive or better significance to the buyer with the direction of product quality, features, or follow up support (Allen \& Helms, 2006; Porter, 1985). Hence, business adopting differentiation strategy can allege higher cost for goods or services based on features, allocation system, quality of service, or delivery channels (Allen \& Helms, 2006; Porter, 1985; Nandakumar, 2011; Teeratansirikool, et al., 2013). The value possibly will be valid or apparent in line with fashion, brand name, or imaged (Porter, 1985; Nandakumar et al., 2010). The differentiation strategy appeals to complex or well familiar customer that are concerned with uniqueness or quality of product and willing to give benefit cost (Allen \& Helms, 2006; Porter, 1985; Nandakumar et al., 2011).

The relationship between strategy and performance has been examined in numerous works, both theoretically and empirically (Hingley, Sodano, \& Lindgreen, 2008; Pehrsson, 2016; Teeratansirikool, 2013). In empirical studies, the linkage between strategy and performance is typically operationalized by using various measures and explicit ideas of causality fuelled by advancements in strategy research (Hingley, Sodano, \& Lindgreen, 2008; Pehrsson, 2016). There are number of researches who established that business that select differentiation as competitive strategy produce better performance than rivals (Allen \& Helms, 2006; Teeratansirikool, 2013). Previous literatures have elaborate differentiation strategy as one of the suitable strategy in competitive strategy for a business to improve their performance (Alsiwidi \& Al-Hosan, 2012; Birjandi et al., 2014; Hilman \& Narentheren, 2015). Allen and Helms (2006) discussed that company that chooses an appropriate generic strategy can achieve reasonable competitive advantage. Allen and Helms (2006) established that differentiation strategy is significant and vital to performance. While Hingley et al., (2013) argues that all depends on several factors (environment). Conversely, the finding is different with the research done by Verbeeten and Boons (2009) that reveals no proof for the assertion that performance measurement of the strategic priorities of the firm significantly affects performance (Nandakumar et al., 2011).

In a recent theoretical assessment of the munificence Castrogiovani, (1991); Goll and Rasheed, (2004) distinguished between three different kinds of munificence: capacity, growth/decline, and opportunities/threat. Therefore capacity means the level of resources available to the business, while growth/decline means the change in capacity and lastly, opportunities/threat means the extent of unexploited capacity (Goll and Rasheed, 2004). Empirical researches over the years suggest that 
munificence has a great influence on organizational process, structure and strategic performance (Goll and Rasheed, 2004). Business that found not to consider environmental munificence is likely to entrust to behave against the ethical act which may cause change in structure and administrative system (Goll and Rasheed, 2004). McArtthur and Nystry (1991) revealed that environmental munificence relate with strategy and consequently affect business performance this means that environmental munificence change the connection between strategy and performance (Goll and Rasheed, 2004).

The Dynamic Capability (DC) Teece et al. (1997) which is an extension of RBV focused on readjustment of obtainable resources into new proficiency in response to demands from sustained environmental change (Wang and Ahmed, 2007). Dynamic Capability is more precise to certain context such as cultural diverse situation and stress timely responsiveness and reconfiguration of internal and external competence that are congruent with changing business environment (Singh et al., 2013). (Smith, 2010) argues that individuals with high self-esteem believe. Similar to Teece et al. (1997), we define dynamic capabilities as the firm's processes that use resources-specifically to integrate, reconfigure, gain and release resources-to match and even create market change. Dynamic capabilities thus are the organizational and strategic routines by which firms achieve new resource configurations as markets emerge, collide, split, evolve, and die. Eisenhardt and Martin (2000) used the term 'combinative capabilities' to describe organizational processes by which firms synthesize and acquire knowledge resources, and generate new applications from those resources. Therefore this study used dynamic capability considering the variables in this study that business can identify their ability to integrate, build, and reconfigure internal and external competences to address rapidly changing situation.

Thus, the literature shows no uniformity concerning the trend of the association between business level strategy and business performance, Hence, the mixed results further urged to examine and validate infection between the business level strategy and performance (Allen \& Helms, 2006; Alsiwidi \& Al-Hosan, 2012; Birjandi et al., 2014; Banker et al., 2014). Thus, this study hypothesizes the following:

H1: There is a significant effect of differentiation strategy on performance of hotels in Nigeria

H2: There is a significant effect of environmental munificence on performance of hotels in Nigeria.

H3: Does environmental munificence moderates the relationship between differentiation strategy and performance of hotels in Nigeria.

\section{Theoretical Framework}

Based on the above, this study examines the relationships of differentiation strategy on performance of hotels in Nigeria with moderating role environmental munificence. The Theoretical framework for the study is shown in Figure 1.

Figure 1 represents a theoretical framework that incorporates the relationship among variables and develops a new direction towards the hotels performance. Researchers view business can identify their ability to integrate build, and reconfigure internal and external (differentiation and environmental munificence) competences to address rapidly changing situation. Eisenhardt and Martin (2000) used the term 'combinative capabilities' to describe organizational processes by which firms synthesize and acquire knowledge resources, and generate new applications from those resources. In similar view Dynamic Capabilities are the antecedent organizational and strategic routines by which managers alter their resource base-acquire and shed resources, integrate them together, and recombine them-to generate new value-creating strategies (Eisenhardt \& Martin, 2000; Wang \& Ahmad, 2007). As such, they are the drivers behind the creation, evolution, and recombination of other resources into new sources of competitive advantage (Eisenhardt \& Martin (2000; Teece et al., 1997). 


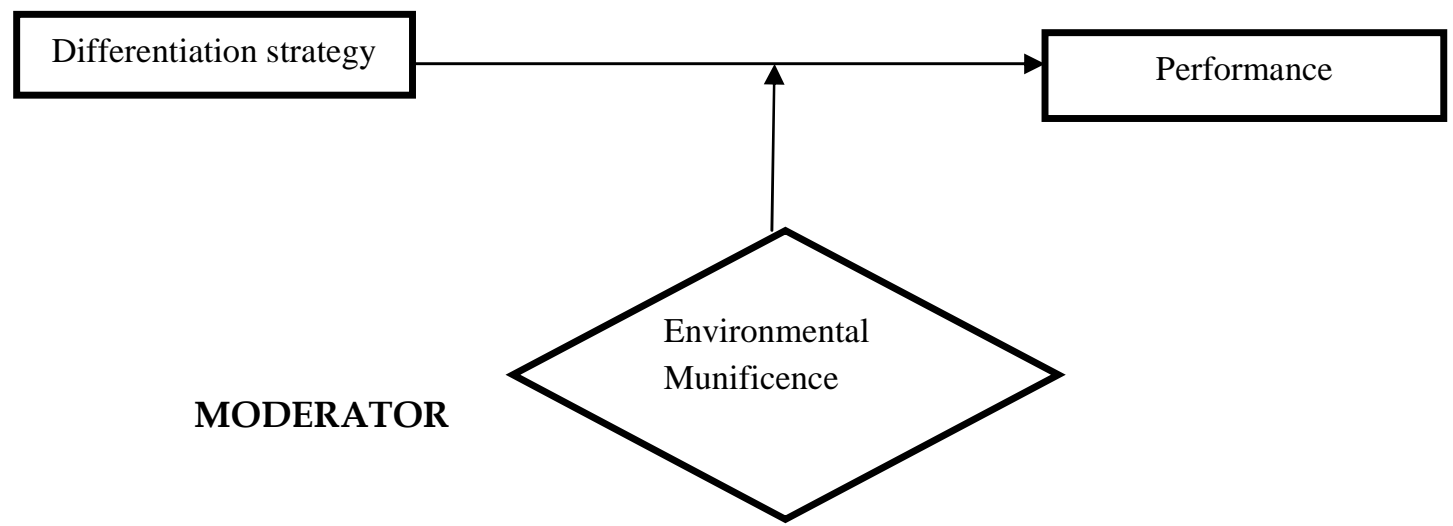

\section{Method}

Figure 1: Theoretical Model

The study employs quantitative research approach. The research setting is non-contrived and time horizon for this research is cross-sectional design using self administering. Questionnaires, the study unit of analysis were owner/manager. Similarly, the population of this study is hotels operating in Kano of North Western Nigeria totalling 83 that registered under the Directory of Kano State Tourism Board, thus, in order to generalize the listed hotels industry, this study adopted the census where every unit in a population is being selected, and this known as complete census. The choosing census as sample size becomes necessary due to small number of population. In additions, the census provide a true measure of population no sampling error, it also provide quit reliable and accurate result (Hilman \& Kaliappen, 2014; Zikmund, Babin, Carr \& Griffin, 2010). This paper adopted Partial Least Squares Structural Equation Modelling (PLS-SEM), due the complexity of the research model. Haenlein \& Kaplan, (2004); Hair, Sarstedt, Ringle, \& Mena, (2012) that PLS-SEM enhanced to be used as a research instrument in many areas like marketing, and other social sciences. Additionally, compared to other covariance based techniques PLS-SEM can accormodate non-normal data and has no restriction in terms of the interaction technique used in moderation test, therefore is a sufficient alternative for statistical test of moderation effect (Chin, Marcolin, \& Newsted, 2003; Hair et al., 2013).

\section{Measures}

Differentiation in this study focuses on Company concerned on given that a unique product or service (Hyatt, 2001). Hence, strategy of differentiation is usually build around firm-specific and product-specific creativity and marketing effort that will find it difficult or easy to imitate quickly. Business that concerned on differentiation strategy, in many cases emphasizes the degree of service and support. While a basic level of service and support may be easy to imitate, increasing these levels beyond the basic level involve substantial amounts of training differentiation attributes and the measurement scale was adapted from Luo and Zhao (2004); Nandakumar et al. (2011) and modify in order to suit the context of the study, the items were tested and achieved a Crobach alpha of 0.776 (Nandakumar et al., 2011).

Environment munificence is refers as the availability or scarcity of significant resources needed by business operating inside the environment (Aminu \& Shariff, 2015; Dess \& Beard, 1984), the resources available inside the environment usually influence the survival and growth of business living within the environment (Dess \& Beard, 1984; Jaiyeoba, 2013). Castrogiovanni (1991) argued that environmental munificence describes the capacity of environment to encourage organizations in the marketplace. Therefore, the study operationally measure environmental munificence as moderating variable measured using 8 items adapted from Tang (2008) and modified in order to suit 
the context of the study. All the 8 items will be measured using seven point Likert-type scales $(1=$ Strongly Disagree to 7 = Strongly Agree).

Performance is operationalized as extent to which business records a success or otherwise in a given period of time. The performance scale in this study uses both objective (financial) and subjective (non- financial) measures is adapted from the evaluated using items adapted from Gorondutse and Hilman, (2016); Hilman (2009) and Kaplan and Norton (1996). Respondents were requested to specify the performance of their hotels in the past three years as compared to the performance of their key opponents in the industry $(1=$ Significantly Decrease to $7=$ Significantly Increase).

\section{Results}

The descriptive statistics and Pearson correlations among the studied variables for the quantitative study are shown in Table 1. Mean and standard deviation are considered to be the important descriptive statistics for interval and ratio scale (Sekaran \& Bougie, 2013). The present study used seven point Likert scale,. Table 1 under describes the mean and standard deviation of the entire variables used in this study. Performance recorded the highest mean $(M=4.95, S D=0.91)$ while environmental munificence has the lowest mean $(\mathrm{M}=4.02, \mathrm{SD}=1.04)$. Therefore, the entire variables means were in the range of high level.

Table 1

Variables Mean and Standard Deviation of the Study

\begin{tabular}{llll}
\hline Items & Description & Mean & SD \\
\hline 1 & Performance & 4.95 & 0.91 \\
2 & Differentiation & 4.61 & 0.93 \\
3 & Environmental Munificence & 4.02 & 1.04 \\
\hline
\end{tabular}

Multicollinearity is other statistical postulations in which two or more predictive constructs in a multiple regression are extremely interrelated. This study checked multicollinearity through tolerance value and variance inflated factor (VIF). To add, Hair et al., (2010) state and recommend that any VIF more than 10 and tolerance value lesser than .10 shows a dilemma of multicollinearity. Table 2 below shows the tolerance value and VIF of the predicting constructs of this study.

Table 2

Multicollinearity Tolerance and VIF Values

\begin{tabular}{|c|c|c|}
\hline \multirow[t]{2}{*}{ Independent variables } & \multicolumn{2}{|c|}{ Collinearity Statistics } \\
\hline & Tolerance & VIF \\
\hline Differentiation Strategy & .988 & 1.012 \\
\hline Environmental Munificence & .980 & 1.021 \\
\hline
\end{tabular}

The result in the table 2 above clearly shows the absence of multicollinearity among the predicting variables due to the fact that the VIF values are less than 10 whereas the tolerance values are more than .10 .

Anderson and Gerbing (1998) provided a two-step modeling approach to determine the quality of items used for measurement and secondly to be able to estimate the relationship between models. These two approaches are also discussed as measurement model and structural model (Hair et al., 2012). hence, the use partial least squares is employed as suggested by Chin et al. (2003) and Smart PLS software (Ringle et al., 2005) was used for this study which can be able to assess the reliability and validity as well as testing the structural / hypothesized model. 


\section{Measurement Model}

The measurement model can be assesses through convergent validity and discriminant validity. Bagozzi, Yi and Philips (1991) and Hair et al., (2010) refer convergent validity as the degree to which a place of construct meets in measuring the concept on the construct (Bagozzi, et al., 1991; Hair, et al., 2010). Looking at the Table 3 reveals that the AVE values between 0.647 to 0.756 and the $\mathrm{CR}$ values of the constructs above the recommended assessment of 0.7 , which ranges between 0.879 to $0.939 \mathrm{it}$, can be established that the measurement model has a sufficient degree of convergent validity.

Table 3

Construct Convergent Validity and Reliability

\begin{tabular}{|c|c|c|c|c|c|}
\hline Variable & Items & $\begin{array}{l}\text { Factor } \\
\text { Loadings }\end{array}$ & $\begin{array}{l}\text { Cronbachs } \\
\text { Alpha }\end{array}$ & $\begin{array}{l}\text { Composite } \\
\text { Reliability }\end{array}$ & AVE \\
\hline \multirow[t]{5}{*}{ Performance } & FP01 & 0.906 & 0.918 & 0.939 & 0.756 \\
\hline & FP02 & 0.936 & & & \\
\hline & FP03 & 0.914 & & & \\
\hline & FP04 & 0.790 & & & \\
\hline & FP06 & 0.789 & & & \\
\hline \multirow[t]{6}{*}{ Differentitiation } & DS01 & 0.769 & 0.920 & 0.936 & 0.713 \\
\hline & DS02 & 0.906 & & & \\
\hline & DS03 & 0.810 & & & \\
\hline & DS04 & 0.892 & & & \\
\hline & DS05 & 0.769 & & & \\
\hline & DS06 & 0.906 & & & \\
\hline \multirow[t]{4}{*}{ Environmental munificence } & BE01 & 0.779 & 0.819 & 0.879 & 0.647 \\
\hline & BE02 & 0.792 & & & \\
\hline & BE03 & 0.862 & & & \\
\hline & BE04 & 0.780 & & & \\
\hline
\end{tabular}

Measurement Model

Discriminant Validity

Having discussed on convergent validity above this section explained on discriminant validity. Discriminant validity refers to the level to which a set of construct can truly be different from other construct. In investigating discriminant validity of the measurement model, this study employed Fornell and Lacker (1981) criteria. Table 4 Indicate the correlation matrix in which the diagonal element represent the square root of the average variance extracted of the latent constructs. The result of the correlation matrix indicated in the table below ensures that the discriminant validity is confirmed.

Table 4

Discriminant Validity

\begin{tabular}{llllll}
\hline & & 1 & 2 & 3 & 4 \\
\hline 2 & Differentiation & .844 & & & \\
3 & Environmental & .167 & .804 & & \\
& Munificence & & & &
\end{tabular}

$\begin{array}{lllll}4 & \text { Performance } & .340 & .706 & .869\end{array}$

Note: The bolded values in diagonals represent the square root of the AVE whilethose off the diagonals represent latent variable correlations

\section{Structural Model}

After a careful assessment of the measurement model in figure 2 the section examined the structural Model for this study. Hair et al., (2006) viewed Structural model as a model that expresses about the reliance of association in the hypothesized model. In terms path coefficient, partial least squares as argued by Argawal and Karahanna (2000), is just like the standardized beta coefficient in regression analysis. The fundamental objective of structural model is to test the hypothesized 
relationships among constructs. Initially, the study focused on model evaluation and secondly, assessed the assumption of regression and correlation of variables. The structural model evaluation continues with an examination of the direct relationships and follow by indirect that is moderation testing.

The $\mathrm{t}$ - values for this research be estimated using a 5000 re-sampling iterations in recurring Bootstrapping as recommended by Hair et al., (2014). It can equally be justified that chosen a 5000 sample is for ensuring that each model parameter has experimental sampling sharing and the standard deviation of the distribution will serve as proxy of the parameter for statistically standard error (Hair et al., 2012).

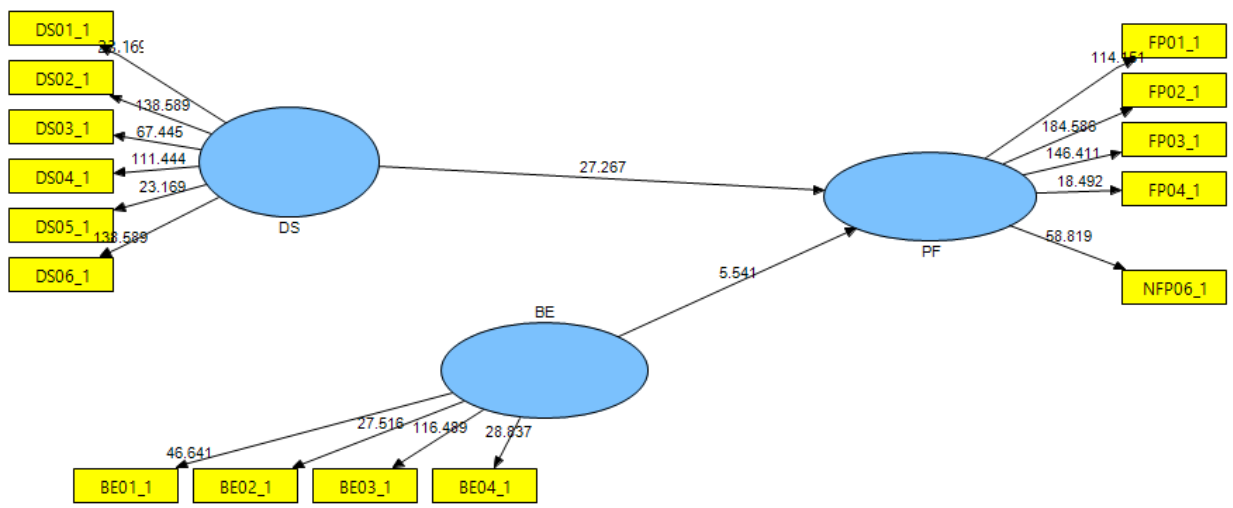

Figure 2

Structural model

Table 5

Result of Hypothesis Testing

\begin{tabular}{lcclll}
\hline & Beta & $\begin{array}{c}\text { Standard } \\
\text { Error }\end{array}$ & t-value & P-Value & Decision \\
\hline EM -> PF & 0.272 & 0.043 & 5.541 & 0.000 & Supported \\
DS -> PF & 1.182 & 0.049 & 27.266 & 0.000 & Supported \\
\hline
\end{tabular}

The above Table 5 indicated that all the study hypotheses were accepted and possess a $\mathrm{t}$ value which is greater than 1.96 shown an adequate support for the two direct hypotheses. The $R^{2}$ value indicated that, all the study variables of differentiation strategy, and environmental munificence are capable of influencing $87.9 \%$ of the changes in the dependent variable which is the performance.

Table 6

Effects of Differentiation, Environmental Munificence on Performance

\begin{tabular}{ll}
\hline Constructs & R Square \\
\hline Cost leadership & \\
Differentiation & \\
Environmental Munificence & 0.879 \\
\hline
\end{tabular}

Note: The study variables explain $87.9 \%$ variation in Performance

Moderating effect size

Table 6 above indicated the result of holistic effect of differentiation strategy, environmental munificence on performance, hence, the need for ascertaining change in $r$ square from the main model through the calculation of the effect sizes of the predicting variables. Therefore, only the results of the effect size $F 2$ of the two (2) hypotheses that were statistically supported are reported. The effect size F2 is calculated using the formula advanced by Cohen (1988) is used: 
Thus: $F 2=\underline{\mathbf{R}^{2} \text { included }-\mathbf{R}^{2} \text { excluded. }}$

\section{$1-R^{2}$ included}

Where:

$i=$ main effect model (without the moderator)

$m=$ interaction effect model (with the moderator)

We can calculate the $f 2$ by filling in the $2 \mathrm{R} 2$ values which we have already noted down

$$
\begin{gathered}
f 2=\frac{0.879-0.868}{1-0.879} \\
f 2=0.091
\end{gathered}
$$

We interpret the $f 2$ by following the guidelines given in Cohen (1988), as follows:

\subsection{Small}

\subsection{Medium}

\subsection{Large}

Therefore, in line with above $\mathrm{f} 2$ is 0.091 , this study can revealed that the effect size is small as per Cohen (1988). Based on this, Chin et al (2003) state that small effect size $f 2$ does not necessarily mean that the underlying moderator effect is negligible, even a small interaction effect can be meaningful under extreme moderating circumstances, if the resulting beta changes are meaningful, then it is significant to take these situation into considerations (Chin et al., 2003).

\section{Predictive Relevance of the Model}

PLS Predictive relevance of the model is intended to evaluate the predictive capability of a particular model. Hair et al., (2012) asserted that predictive relevance is represented by Q2; ${ }^{2}$ does not only evaluated how values are built around the model but also assesses the parameter estimates. The cross validated redundancy assesses the capability of the model to predict the endogenous variables and hence demonstrates the quality of the model. The Table 7 shows the construct cross validated redundancy

Table 7

Construct Cross Validated Redundancy

\begin{tabular}{llll}
\hline Total & SSO & SSE & $1-S S E / S S O\left(Q^{2}\right)$ \\
\hline PF & 224 & 131.17 & 0.414 \\
\hline
\end{tabular}

Table 7 above shows that the predictive relevance of the model remains outstanding. Based on the Smart PLS 2.0 results, the obtained cross validated redundancy was established to be 0.414 . Chin, (1988), set three criteria (i) if Q2 is 0.02, then the model has small predictive relevance, (ii) if Q2 is 0.15 , then the model has medium predictive relevance, and (iii) if Q2 is 0.35 , then the model has large predictive relevance. for this reason, the result indicate sufficient prediction quality.

\section{Test of Moderation}

Moderator is a construct that strength the relationship between two constructs, hence that the nature of the influence of independent variable on the criterion will differ in accordance to the degree or value of the moderator (Ramayah, 2014). In this study, a moderating variable of environmental munificence is introduced on the association between differentiation strategy and hotel performance. After the insertion of the interaction term the result of the of the path coefficient established that environmental munificence is found to moderate on the association between differentiation strategy and hotel performance. 


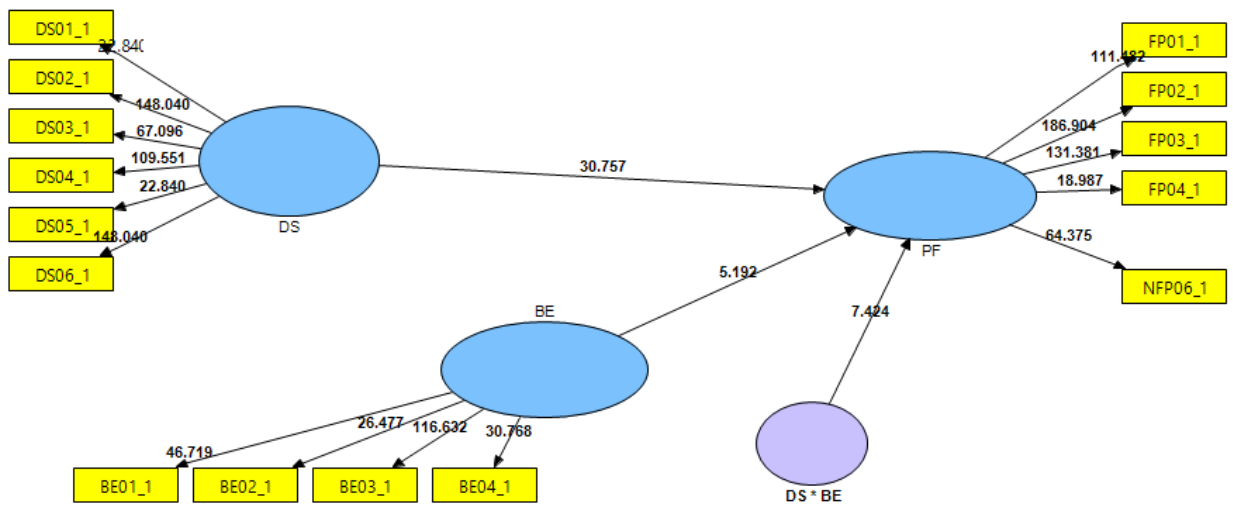

Table 8

Result of moderation Test of EM on the relationship between DS and performance.

\begin{tabular}{llllll}
\hline & Beta & $\begin{array}{l}\text { Standard } \\
\text { Error }\end{array}$ & t-value & P-Value & Decision \\
\hline DS -> PF & 1.252 & 0.040 & 30.757 & 0.000 & Supported \\
DS * EM -> PF & 0.142 & 0.019 & 7.423 & 0.000 & Supported \\
\hline
\end{tabular}

\section{Discussion}

The discussion of the study basically focused on the research objectives of this study. Research objectives state that to find the influence of differentiation strategy on performance of hotels with moderating role of environmental munificence. The result of a moderation test of the environmental munificence on the relationship between differentiation strategy and performance indicated that the variable is able to explain $87.9 \%$ of the model. The product indicator approach results indicated that differentiation has the following values $(\beta=-0.142, \mathrm{t}=7.423, \mathrm{P}=0.000)$. Therefore $\mathrm{H}_{3}$ is supported.

Therefore, this study has confirmed that environmental munificence can strengthen the relationship between differentiation strategy, and performance of Nigerian hotels. Similarly, if hotels manager particularly in Nigeria can use environmental munificence with regards to creating friendly environment and support of community and media will surely influences performance of hotels in Nigeria. In addition this is result is in line with Tang (2008) who reveals that high environmental munificence lead to higher performance.

The literature review in his study indicated that not many studies have looked at hotels organisations in the developed economics, and out of these, only a few studies if any have focussed on services industry. The study presented suitable proof for the hotels' superiors for creating strategic tactics in determining business level strategies, and performance measurements in their efforts to make every effort for the superior organizational performance. The paper has contributed in testing these instruments in an African context. Similarly, it has contributed in developing and testing research hypotheses.

The finding of this study would be of relevance to policy makers such hoteliers and Kano state tourism board in designing the future environmental programs that create friendly, support and utilized the available scarce resources as this will help in energizing and promoting customer spirit to patronize Nigerian hotels. as it will guide and assist hotels managers by given guidance on particular resource patterns can give precious return leading to sustainable performance. Thus, the increase in their performance will help toward increase in gross domestic production (GDP) and sustainable economic development. 


\section{Conclusions and recommendations}

The findings of this study established that, the first research objective is to examine the influence differentiation strategy on performance hotels in Nigeria with moderating role of environmental munificence. The result of Smart PLS 2.0 software indicated that the effect differentiation strategy on performance hotels in Nigeria is supported. Hence, the need for hotels regulators put more effort in cost reduction strategies and also emphasize on partnering opportunities with a view of getting competitive advantage. Also, examine the effect environmental munificence on performance hotels in Nigeria. The finding of this study is supported. This shows that environmental munificence is a good predictor of hotels performance in Nigeria. Therefore, all issues regarding environmental munificence are a very significant factor in determining performance.

Based on the study findings, it was reported that environmental munificence was a moderator to differentiation strategy. Therefore, the ability of hotels manager to create friendly, support community and extend to which hotels utilize available of resource is a good pointer of success, and can give them an edge over and above rivals, hence, the tendency of remaining relevant in its immediate environment.

The results lend support and provide valuable insights into the influence of differentiation strategy on performance, but it has few limitations, as our survey did not contain/confine all potentially relevant constructs in establishing effects on performance of hotels. Nevertheless, we have designed our research to capture/to measure our most relevant and most researched construct; exclusion of other variables does not detract us from the valuable research findings. This article makes important contribution in adding to the literature on performance research. By employing environmental munificence, this study demonstrated how moderating variable can influence the relationship between exogenous and endogenous constructs. This will continue be a subject of fruitful research that could help researchers and policy makers to better understand these construct and reducing the prevalence of this phenomenon.

In any research like present study have some limitations. The first limitation is that, even though there are so many variables that can measure organizational performance, this study is limited to only differentiation strategy, and environmental munificence. One other limitation of this study is that, data were collected from Kano state in north western Nigeria, which might not be a basis for generalization. In spite of these shortcomings, the present study provides a basis for examining the association between differentiation strategy, and performance of Nigerian hotels, with the moderating effects of environmental munificence. The paper uses manager perception; future research may use other owners/managers perception in performance rating. This study employs quantitative research design; future research may use mixed methods/triangulation, using both quantitative and qualitative questionnaire and interview. Finally, this study recommends the use of the structural equation modeling (SEM) for data analysis in the future studies.

\section{References}

Allen, R.S. \& Helms, M.M. (2006), "Linking strategic practices and organizational performance to Porter's generic strategies", Business Process Management Journal, 12(4), 433-454.

Al-siwidi, A.K., \& Al-Hosam, A. (2012). The effect of entrepreneurial orientation on the organizational performance: A study on Islamic banks in Yemen using the Partial Least Squares approach. African Journal of Business Management, 2(1), 156-164

Aminu, M. I., \& Shariff, M. N. (2015). Determinants of SMEs Performance in Nigeria: A Pilot Study. Mediterranean Journal of Social Sciences, 6(1), 156-164

Anderson, J. C., \& Gerbing, D. W. (1988), Structural Equation Modeling in Practice: A Review and Recommended Two-Step Approach, Psychological Bulletin, 103 (3), 411-423.

Bagozzi, R.P., Yi, Y., \& Phillips, L.W. (1991). Assessing construct validity in organizational research.Administrative Science Quarterly, 36(3), 421-458. 
Banker, R. D. \& Tripathy R. M. A. (2014),"Does a differentiation strategy lead to more sustainable financial performance than a cost leadership strategy?, Management Decision, 52(5), 872 896.

Birjandi, H., Jahromi, N. M., Darasi, S. M., \& Birjandi, M. (2014). The Effect of Cost Leadership Strategy On ROA and Future Performance of Accepted Companies in Tehran Stock

Exchange. Research Journal of Finance and Accounting,5(70, 152-158.

Cavusgil, S.T., Ghauri, P.N. \& Akcal, A.A. (2013), Doing Business in Emerging Markets, 2nd ed., SAGE, London.

Chin, W. W. (1998a), Issues and opinion on structural equation modeling, MIS Quarterly, 22(1), VII-XVI.

Chin, W.W., Marcolin, B.L. \& Newsted, P.R. (2003). A partial least squares latent variable modelling approach for measuring interaction effects: results from a Monte Carlo simulation study and an electronic-mail emotion/adoption study, Information Systems Research, 14(2), 189-217.

Cohen, J. (1988). Statistical Power Analysis for the Behavioral sciences, (2nded). New Jersey: Lawrence Erlbaum Associates.

Dess, G. G., \& Beard, D. W. (1984). Dimensions of organizational task environments. Administrative Science Quarterly, 52-73.

Eisenhardt, K.M. \& Martin, J. (2000). Dynamic capabilities: what are they?, Strategic Management Journal, 21( 10/11), 1105-1121.

Figueiredo, P.N. (2011). The role dual embeddedness in the innovative performance of MNE subsidiaries: evidence from Brazil. Journal of Management Studies, 48(2), 417-440.

Fornell, C., and Larcker, D. F. (1981). Evaluating structural equation models with unobservable and measurement error. Journal of Marketing Research,18, 39- 50.

Goll, I., \& Rasheed, A. A. (2004). The moderating effect of environmental munificence and dynamism on the relationship between discretionary social responsibility and firm performance. Journal of Business Ethics, 49(1), 41-54.

Gorondutse, A.H., \& Hilman, H. (2016). The Moderation Effect of Organizational culture on the Relationship between Commitments of Corporate Social Responsibility (CSR) and Performance of SMEs in Nigeria. Journal of General Management, 42(1), 65-77.

Hair, J. F., Jr., Black, W. C., Babin, B. J., Andersen, R. E., \& Tatham, R. L. Analysis (6th ed.). Upper Saddle River, NJ:Pearson Prentice Hall.

Hair, J., Black, J. W., Babin, B. J., \& Anderson, E. R. (2010). Multivariate data analysis United State of America: Pearson Prentice Hall.

Hair, J.F., Sarstedt, M., Pieper, T.M. and Ringle, C.M. (2012). The use of partial least squares structural equation modelling in strategic management research: a review of past practices and recommendations for future applications. Long Range Planning, 45(5/6),320-340.

Hilman, H. (2009), "Relationship of competitive strategy, strategic flexibility and sourcing strategy on organizational performance", unpublished PhD dissertation,Universiti Putra Malaysia, Selangor.

Hilman H, \& Kaliappen, N. (2014). Strategic Role of Customer Orientation in Differentiation Strategy and Organizational Performance Nexus: A Partial Least Square (PLS) Approach. Research Journal of Applied Sciences, Engineering and Technology 7(19): 4150-4156,

Hilman H, \& Kaliappe, N. (2015). Innovation strategies and performance: are they truly linked?. World Journal of Entrepreneurship, Management and Sustainable Development 11(1), 48-63.

Hingley, M., Sodano, V., \& Lindgreen, A., (2008). Differentiation strategies in vertical channels A case study from the market for fresh produce. British Food Journal, $110 \quad$ (1)42-61

Jaiyeoba, O.O. (2013). The effect of environmental munificence and market orientation dimensions on performance of small business in Botswana, Business and Economic Research, 3(2), 246-254 
Kaplan, R.S. \& Norton, D.P. (1996), The Balanced Scorecard: Translating Strategy ～into Action, HBS Press, Boston, MA.

Luo, Y. \& Zhao, H. (2004), "Corporate link and competitive strategy in multinational enterprises: a perspective from subsidiaries seeking host market penetration, Journal of International Management. 10(1),77-105.

Nandakumar, M. K., Ghobadian, A., \& Regan, N.O. (2011). Business-level strategy and performance: The moderating affect of environment and structure. Management Decision, 48(6), 907-939.

Ngandu, H. M., (2014). Ifluence of competitive strategies on performance of Hotel: A case of Thika Town Kenya. Unpublished Thesis.

Pehrsson, A. (2016). How does a foreign subsidiary's differentiation strategy fit competitive dynamics and mandate?, European Business Review, 28( 6), 690 - 708

Porter, M.E. (1980) Competitive Strategy. Free Press.

London, T. and Hart, S.L. (2004). Reinventing strategies for emerging markets: beyond the transnational model. Journal of International Business Studies, 35, 350-370.

Ringle, C., Wende, S., \& Will, A. (2005). SmartPLS 2.0 M3. Hamburg: University of Hamburg. Retrieved June 6th 2015, from http:/ / www.smartpls.de

Sekaran, U., \& Bougie, R. (2013). Research Methods for Business: A skill Building Approach, Six Edition. United Kindom: John Wiley \& Sons Ltd.

Smith, A. (2010). The theory of moral sentiments. London: Penguin Classics

Tang, J. (2008). Environmental munificence for entrepreneurs: entrepreneurial alertness and commitment. International Journal of Entrepreneurial Behaviour \& Research, 14(3), 128-151.

Teece, D., Pisano, G. \& Shuen, A. (1997). Dynamic capabilities and strategic management, Strategic Management Journal, 17, 509-533.

Teece, D.J. (2014). A dynamic capabilities-based entrepreneurial theory of the multinational enterprise, Journal of International Business Studies, 45, 8-37.

Teeratansirikool, L., Siengthai, S., Badir, Y., \& Charoenngam, C. (2013). Competitive strategies and firm performance: the mediating role of performance measurement, International Journal of Productivity and Performance Management, 62(2), 168 - 184.

Tourist Report: The business hotel industry in selected East and West African countries, May 2012. Retrieved from www.idc.co.za/images/content/tourism_report_2012.

Yuliansah, Y., Rammal, H. G., \& Rose, E. (2016). Business strategy and performance in Indonesia's service sector. Journal of Asia Business Studies, 10(2), 164 - 182.

Zikmund, W. G., Babin, B. J., Carr, J. C., \& Griffin, M. (2010). Business research methods.Canada: SouthWestern, Cengage Learning. 